\title{
How self-regulated learning strategies interfere between metacognitions and decisional procrastination
}

\author{
Valeria DE PALO ${ }^{1}$, Lucia MONACIS ${ }^{2}$, Maria SINATRA ${ }^{3}$ \\ ${ }^{1}$ Departamento de Ciencias Humanas. Universidad de Foggia (Italia) \\ ${ }^{2}$ Departamento de Ciencias Humanas. Universidad de Foggia (Italia) \\ ${ }^{3}$ Departamento de Educación, Psicología y Comunicación. Universidad de Bari (Italia).
}

(Received on March 29, 2018; Accepted on September 3, 2018)

\begin{abstract}
Generally conceptualized as a failure of performance, procrastination has been a central focus of psycho-educational research. Among the various facets of the construct, decisional procrastination has been scarcely analyzed in relation with self-regulated learning strategies. Assuming a cognitive standpoint we investigated the linkage between decisional procrastination and metacognitive beliefs about procrastination, taking into account self-regulated learning strategies as potential mediators. A sample of 296 undergraduate students filled out a questionnaire measuring metacognitive beliefs about procrastination, concentration on academic tasks and interests in academic success, and decisional procrastination. The hypothesized model was partially confirmed: Results from structural equation model indicated that: (1) positive metacognitive beliefs about procrastination had an adverse impact on both concentration and interests; (2) concentration mediated the relationship between positive metacognitions and decisional procrastination. Although the results were preliminary in nature, they provided a basis for examining procrastination as a barrier to academic success. Some professional indications for education were suggested.
\end{abstract}

Keywords: Decisional procrastination, self-regulated learning, metacognitive beliefs

\section{Cómo las estrategias de aprendizaje autorregulado afectan la metacognición y la procrastinación decisional}

RESUMEN: Generalmente conceptualizado como un fracaso de la performance, la procrastinación ha sido un tema central de la investigación en la psicología educativa. Entre la varias facetas del constructo, la procrastinación de tipo decisional ha sido escasamente analizada en relación a las estrategías de aprendizaje autorregulado. Adoptando un punto de vista cognitivo, hemos investigado la relación entre la procrastinación decisional y las creencias metacognitivas sobre la procrastinación, teniendo en cuenta las estrategías de aprendizaje autorregulado como posible mediadores. Una muestra de 296 estudiantes universitarios han cumplimentado una serie de cuestionarios que medían la creencias metacognitivas sobre la procrastinación, la concentración en las tareas académicas y el interés en el éxito académico y la procrastinación decisional. El modelo planteado fue confirmado parcialmente. Los resultados del modelo de ecuación estructural mostraron que: (1) las creencias metacognitivas positivas sobre la procrastinación tuvieron un impacto negativo sobre la concentración 
y el interés; (2) la concentración medió la relación entre las creencias metacognitivas positivas y la procrastinación decisional. Aunque los resultados tenían un carácter preliminar, ellos aportaron un fundamento para examianar la procrastinación como un obstáculo al éxito académico. Fueron sugeridas algunas indicaciones profesionales para la educación.

Palabras claves: Procrastinación decisional, aprendizaje autorregulado, creencias metacognitivas

Correspondencia: Valeria de Palo. Departamento de Ciencias Humanas. Universidad de Foggia (Italia).valeria.depalo@unifg.it

\section{Introduction}

Generally conceptualized as a failure of performance (Baumeister \& Heatherton, 1996; Baumeister, Heatherton, \& Tice, 1994; Ferrari, 2001), procrastination has been variously identified according to the specific context of intervention: educational/academic (Balkis \& Duru, 2015; Balkis, Duru, \& Bulus, 2013; Klassen, \& Kuzucu, 2009; Suldo, Shaunessy, Michalowski, \& Shaffer, 2008; Zhou \& Kam, 2017), everyday (Lay, 1986; Milgram, 1988; Milgram, Srolof, \& Rosenbaum, 1988), arousal seeking (Steel, 2010), decisional, behavioralavoidant procrastination (see Milgram \& Nette 2000; Orellana-Damacela, Tindale, \& SuarezBalcazar, 2000), etc. The present study focused on decisional procrastination intended as a form of chronic or dysfunctional procrastination (Ferrari, 2010) whose framework dates back to Janis and Mann's (1977) “conflict-theory model of decision-making”.

Within the specific procrastination literature a strong debate emerged about whether decisional procrastination and general (or behavioral) procrastination are two overlapping constructs (Tibbett \& Ferrari, 2015). Because of their high correlation, decisional procrastination should not be considered separately from general procrastination (Steel, 2007, 2010), for instance, in line with Rassin's (2007) model of indecisiveness according to which procrastination is a manifestation of indecisiveness. Conversely, when defined as a kind of decision avoidance, the construct should be analyzed independently from general procrastination (e.g., Anderson, 2003). Following Gollwitzer's model of action phases (Gollwitzer, 1996), van Hooft and colleagues (2005) discussed procrastination in terms of a predecisional or deliberative phase, where individuals deliberate which goal to pursue, and a postdecisional or implemental phase, which concerns planning when, where and how to act in accordance with the goal intention. Consequently, decisional procrastination was believed to be different from general procrastination, since the former operates earlier in the action process and the latter is more proximal to behavior. This perspective has been supported by Tibbett and Ferrari (2015) who argued that, despite of the high correlation between decisional and general procrastination, the two constructs are different due to their impacts on outcome variables and to their personality predictors.

According to a further approach, decisional procrastination is a cognitive process related to the voluntary delay of start or completing tasks. That is, indecision may drive chronic behavioral procrastinators to create excuses that justify why they do not focus on the behavior (DíazMorales \& Ferrari, 2015). In this sense, indecision appears to be a last-minute protective strategy intertwined with generalized procrastination (Tibbett \& Ferrari, 2015). 
Taking this cognitive perspective, findings from Spada and colleagues' (2006) research provided evidence of the role played by negative metacognitive beliefs about cognitive confidence in predicting behavioral procrastination, and by positive beliefs about worry in predicting decisional procrastination: the first ones may lead individuals to doubt their task performance capabilities, adversely impacting on motivation, task initiation and persistence, while the second ones may facilitate the activation of perseverative thinking akin to worry which would hinder decision-making processes. Subsequently, Fernie and Spada (2008) verified the existence of two kinds of metacognitive beliefs about procrastination in chronic procrastinators: (1) positive metacognitive beliefs concerning the usefulness of procrastination in improving cognitive performance, and (2) negative metacognitive beliefs concerning the uncontrollability of procrastination.

Thanks to the above described characteristics, decisional procrastination has received a growing interest especially in academic settings, starting from the end of the 1980s when Beswick, Rothblum, and Mann (1988) identified the tendency to procrastinate decisions as a modest but significant antecedent of academic procrastination, since students were deeply conflicted about the choice of the course they were studying or the project they were following. The research was continued in terms of associations between non-adaptive decision-making coping patterns, students' life satisfaction (e.g., Deniz, 2006), career decision-making (Di Fabio, 2006), well-being (e.g., Yilmaz, Arslan, Sarïcaoğlu, \& Yilmaz, 2013), and self-regulated learning (SRL) (de Palo, Limone, \& Sinatra, 2017; de Palo, Monacis, Miceli, Sinatra, \& Di Nuovo, 2017).

As regards SRL, there is a large amount of research examining the relationship between this construct and academic procrastination. According to Zimmerman and Schunk's (1989) conceptualization, SRL refers to students' self generated thoughts, feelings, and actions oriented toward the achievement of their goals. As self-regulated learners are motivated, actively planful, and able to manage their own learning, they should not frequently procrastinate (Cao, 2012a; Wolters, 2003). However, if the negative association between cognitive and metacognitive learning strategies and academic procrastination has been extensively demonstrated (Corkin, Shirley, \& Lindt, 2011; Howell \& Watson, 2007; Howell, Watson, Powell, \& Buro, 2006), research on the relation between self-regulated learning components and decisional procrastination is still scarce.

Assuming a cognitive standpoint we sought to investigate the nature of the linkage between students' reported level of decisional procrastination and their metacognitive beliefs about procrastination, taking into account some components of self-regulated learning strategies as potential mediators.

As Weinstein, Schulte and Palmer's (1987) model of strategic learning had at its core the learner with his/her personality, prior knowledge, and school achievement history, and around it three interactive components, skill, will, and self-regulation, it seemed to be one of the most suitable theoretical framework to understand the above described characteristics of selfregulated learning strategies in relation to decisional procrastination. We supposed that one aspect from the self-regulation component, i.e., concentration, and one from the will 
component, i.e., attitude, would interfere in the relationship between students' metacognitive beliefs about procrastination and decisional procrastination.

Particularly, as concentration "helps students to focus their attention on school-related activities [...], rather than on distracting thoughts, emotions, feelings, or situations" (Weinstein, Palmer, \& Acee, 2016, p. 14), as well as maladaptive metacognitions influence the selection and implementation of poor attentional strategies (Fernie, McKenzie, Nikčević, Caselli, \& Spada, 2016), we hypothesized that both positive and negative metacognitive beliefs about procrastination would reduce students' capacity to focus on their academic tasks, thus increasing the tendency to procrastinate a decision. Furthermore, as metacognitive beliefs are maladaptive coping strategies that generate information concerning the inability to control thoughts and emotions in a desired way (Fernie, Spada, M. M., Nikčević, Georgiou, \& Moneta, 2009; Wells, 2000), they were expected to negatively affect students' attitudes and interest in performing academic tasks successfully, hence fostering their indecisiveness.

\section{Method}

\section{Participants and procedures}

The sample was composed by 296 undergraduate students $\left(\mathrm{M}_{\text {age }}=23.07, \mathrm{SD}=2.94 ; 194\right.$ were females) attending the second year of their degree course. Participants were recruited using convenience sampling; they were invited to complete individually a battery of anonymous selfreport questionnaires in approximately 20 minutes. Data were collected from May to June 2017. Potential order effects were controlled by presenting the questionnaires in three randomized orders. Respondents provided a written informed consent before fulfilling the questionnaires. The research was performed in accordance with the ethical principles for conducting research with human participants, as well as with the law of privacy. The English versions of the instruments were translated into Italian separately by the Italian authors of the present study. The translated versions were back-translated into English by a native speaker to establish their comparability. Confirmatory Factor Analyses (CFAs) using a robust estimation method, the Mean and Variance Adjusted Maximum Like lihood (MLMV) were performed to establish the validity of the translated instruments. The Chi-square statistic $\left(\chi^{2}\right)$ and its degree of freedom, the Comparative-Fit-Index (CFI; $\geq .90)$, the Root-Mean-Square-Error-ofApproximation (RMSEA; values close to .06 ) plus its 90\% confidence interval (CI), and the Standardized-Root-Mean-Square-Residuals (SRMR; $\leq .08$ ) (Bentler \& Bonnett, 1980; Hu \& Bentler, 1999) were considered.

\section{Measures}

Two independent subscales of the Learning and Study Strategies Inventory (LASSI - $3^{\text {nd }}$ ed., Weinstein et al., 2016; $1^{\text {st }}$ Ed., Weinstein, Schulte, \& Palmer, 1987) were used to measure Concentration (CON) referred to students' ability in directing and maintaining attention on academic tasks (e.g., "If I get distracted during class, I am able to refocus my attention"), and Attitude (ATT) referred to students' interests in academic success (e.g., "I feel confused and undecided as to what my educational goals should be"). Each subscale comprises 6 items rated on 
a 5-point Likert scale (from $1=$ Not at all typical of me to $5=$ Very much typical of me). Low scores in CON and ATT indicate low abilities to direct and maintain the attention on the task and the tendency to belief that university courses are not relevant or important. Fit indices for the twofactor model indicated acceptable fit to the data, $\chi^{2}=174.373, \mathrm{df}=102, p<.001$; RMSEA $=.052$, $90 \% \mathrm{CI}=.038-.065, p=.403 ; \mathrm{CFI}=.844 ; \mathrm{SRMR}=.079$. However, the factor loadings of two items were smaller than .30 (items 6 of ATT $=.147$, and 75 of CON $=.176$ ). A second CFA excluding these items showed better fit indices, $\chi^{2}=119.125, \mathrm{df}=75, p<.001$; RMSEA $=.047$, $90 \% \mathrm{CI}=.030-.062, p=.605 ; \mathrm{CFI}=.939$; SRMR $=.073$ ). All factor loadings were significant and ranged from .334 to .865 . The internal consistency was found to be satisfactory for both subscales (Cronbach's alpha $=.826$ for CON and .776 for ATT).

The Metacognitive Beliefs About Procrastination Questionnaire (MBPQ; Fernie et al., 2009) was used to assess positive (e.g., "Procrastination allows creativity to occur more naturally") and negative (e.g., "Procrastination makes me feel down") metacognitive beliefs about procrastination through two dimensions, each consisting of eight items rated on a 4-point Likert scale (from 1 = Do not agree to $4=$ Agree very much). Higher scores indicate higher levels of maladaptation in metacognitive beliefs. CFA of the two-factor model yielded poor fit indices, $\chi^{2}=277.453, \mathrm{df}=103, p<.001 ; \mathrm{RMSEA}=.080,90 \% \mathrm{CI}=.069-.091, p<.001 ; \mathrm{CFI}=.764$; $\mathrm{SRMR}=.127$. Items 4 and 7 of the positive metacognitive beliefs dimension did not load on the respective factor and the factor loading of item 15 of the negative metacognitive beliefs dimension was smaller than .30. The second CFA excluding the three items showed better fit indices, $\chi^{2}=131.961, \mathrm{df}=63, p<.001$; RMSEA $=.064,90 \% \mathrm{CI}=.049-.079, p=.064$; CFI $=.90 ;$ SRMR $=.06$. All factor loadings were significant and ranged from .363 to .829 . The internal consistencies were satisfactory (Cronbach's alpha $=.793$ for the Positive beliefs dimension and .830 for the Negative beliefs dimension).

The Procrastination subscale of the Melbourne Decision-Making Questionnaire - Italian version (MDMQ; Mann, Burnett, Radford, \& Ford, 1997; Nota \& Soresi, 2000) was applied to measure decisional procrastination. It comprises 5 items (e.g., "I waste a lot of time on trivial matters before getting to the final decision") rated on a 5-point Likert scale (from $1=$ Not true for $m e$ to $5=$ True for $m e$ ). Higher scores indicate the tendency to postpone the moment in which individuals have to cope with decisional problems. The scale reliability was satisfactory $($ Cronbach's alpha $=.756)$.

\section{Analysis strategies}

Data cleaning involved the inspection of cases with missing values and the check of the univariate and multivariate normality of the scores. As for the univariate normality, the scales scores showed absolute values of skewness $<2.0$ and values of kurtosis $<7.0$ (Kim, 2013). The univariate outliers were also identified using the graphic approach (inspection of Boxplot). A total of 13 cases proved to be outliers and were removed from the dataset. The multivariate outliers were inspected using the Mahalanobis distances and the critical value for each case based on the chi-square distribution values. The procedure yielded only two cases that were removed. 
Preliminary analyses included descriptive statistics (minimum, maximum, means, and standard deviations) of each variable and zero-order correlations to explore the pattern of associations between the constructs taken into account.

The hypothesized model was assessed using structural equation model (SEM) with metacognitive beliefs about procrastination, concentration, attitude, and decisional procrastination as latent variables. The measurement models of metacognitve beliefs, concentration, and attitude were assessed by applying the parcels technique which increases parsimoniousness, reduces various sources of sampling error, and decreases the chances for residuals to be correlated (Little, Cunningham, Shahar, \& Widaman, 2002). Parcels were created using a balancing method in which the scale item with the highest item-scale correlation was combined with the other scale items with the lowest item-scale correlation (Little, 2013). The Maximum Likelihood (ML) estimation method was applied. The model fit was evaluated using the above described fit indices $\left(\chi^{2}\right.$ values associated with its degree of freedom and $p>.05$; the CFI; the RMSEA plus its $90 \% \mathrm{CI}$; the SRMR). Both direct and indirect effects were assessed. Analyses were performed using MPlus 7.0 and SPSS 20.0 for Windows.

\section{Results}

\section{Descriptive statistics}

Table 1 shows the descriptive statistics (minimum, maximum, mean, and standard deviation).

Table 1. Descriptive Statistics For Metacognitive Beliefs About Procrastination, Self-Regulated Learning Strategies, And Decisional Procrastination

\begin{tabular}{lcccc}
\hline & Minimum & Maximum & Mean & $\begin{array}{c}\text { Standard } \\
\text { deviaton }\end{array}$ \\
\hline $\begin{array}{l}\text { Positive metacognitive beliefs } \\
\text { about procrastination }\end{array}$ & 1.00 & 3.83 & 2.23 & .558 \\
$\begin{array}{l}\text { Negative metacognitive } \\
\text { beliefs about procrastination }\end{array}$ & 1.14 & 4.00 & 2.80 & .652 \\
Concentration & 14.00 & 35.00 & 26.97 & 4.517 \\
$\begin{array}{l}\text { Attitude } \\
\text { Decisional procrastination }\end{array}$ & 14.00 & 35.00 & 29.91 & 3.583 \\
\hline
\end{tabular}

\section{Correlations}

Table 2 shows the bivariate correlations between the variables of interest. Results indicated that positive beliefs about procrastination correlated negatively with concentration and attention, and positively with decisional procrastination. The scores of attitude and interest and of concentration and attention were negatively associated with decisional procrastination. No correlations emerged between negative beliefs about procrastination and the other variables. 
Table 2. Bivariate Correlations Between The Variables Of Interest

\begin{tabular}{lcccr}
\hline & $\mathbf{1}$ & $\mathbf{2}$ & $\mathbf{3}$ & $\mathbf{4}$ \\
\hline 1. Positive metacognitive beliefs about & & & & \\
procrastination & & & & \\
2. Negative metacognitive beliefs about & $-.338^{* *}$ & - & & \\
procrastination & $-.174^{* *}$ & .045 & - & \\
3. Concentration & -.117 & .101 & $.478^{* *}$ & - \\
4. Attitude & $.203^{* *}$ & .017 & $-.489^{* *}$ & $-.374^{* *}$ \\
5. Decisional procrastination & & & & \\
$* p<.05 ; * * p<.01$ & &
\end{tabular}

\section{Structural equation model}

As previously mentioned in the introduction, concentration, attitude, and decisional procrastination were hypothesized to be predicted by both positive and negative metacognitive beliefs about procrastination, with concentration and attitude as mediators. The fit indices of the hypothesized model were good, $\chi^{2}(109)=172.445, p<.001$, RMSEA $=.047$, 90\% C.I. $=$ $.033-.060, \mathrm{CFI}=.954, \mathrm{SRMR}=.045$.

Figure 1 depicts the path diagram for the model. As shown, only positive metacognitive beliefs about procrastination predicted negatively concentration and positively decisional procrastination. With regard to mediators, both concentration and attitude negatively predicted decisional procrastination. As for indirect effects, only concentration partially mediated the relationship between positive metacognitions and decisional procrastination $(\beta=.102, p=$ .028 ). The model accounted for $4.2 \%$ of the variance in concentration, $1.7 \%$ in attitude, and $43.4 \%$ in decisional procrastination.

Given that negative beliefs about procrastination proved to be unrelated to concentration, attitude, and decisional procrastination, a second, alternative model excluding these links was tested. The fit indices of this model were better, $\chi^{2}(70)=108.544, p=.002$, RMSEA $=.045$, $90 \%$ C.I. $=.028-.062$, CFI $=.963$, SRMR $=.043$. The classical approach based on the $\chi^{2}$ difference $\left(\Delta \chi^{2}\right)$ test was used to compare the two models. The significant $\Delta \chi^{2}$ value $\left(\Delta \chi^{2}=\right.$ $63.901, \Delta \mathrm{df}=39 p=.007$ ) indicated that the model with fewer parameters fits significantly better than the less restrictive model. Decisional procrastination was negatively predicted by positive metacognitive beliefs, concentration and attitudes. Standardized beta coefficients are shown in Figure 2. A weakly partial mediation emerged between positive beliefs and decisional procrastination through concentration $(\beta=.090, p=.021)$. 


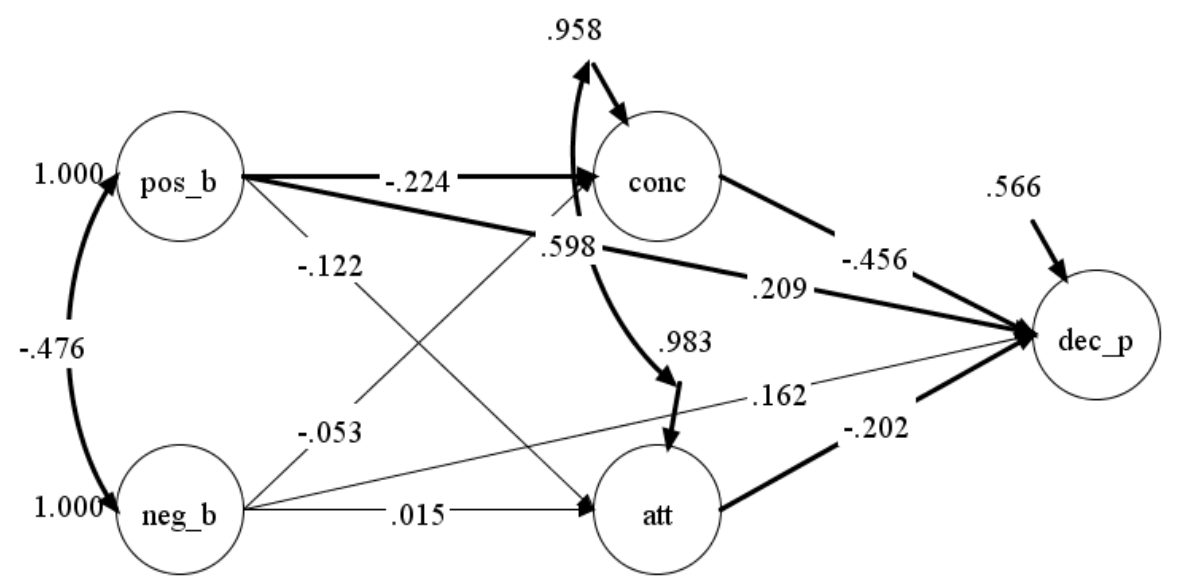

Figure 1. Path diagram of the relationship between positive and negative metacognitive beliefs about procrastination (pos_b, neg_b), concentration (conc), attitude (att), and decisional procrastination (dec_p). Significant paths $(p<.05)$ are in bold.

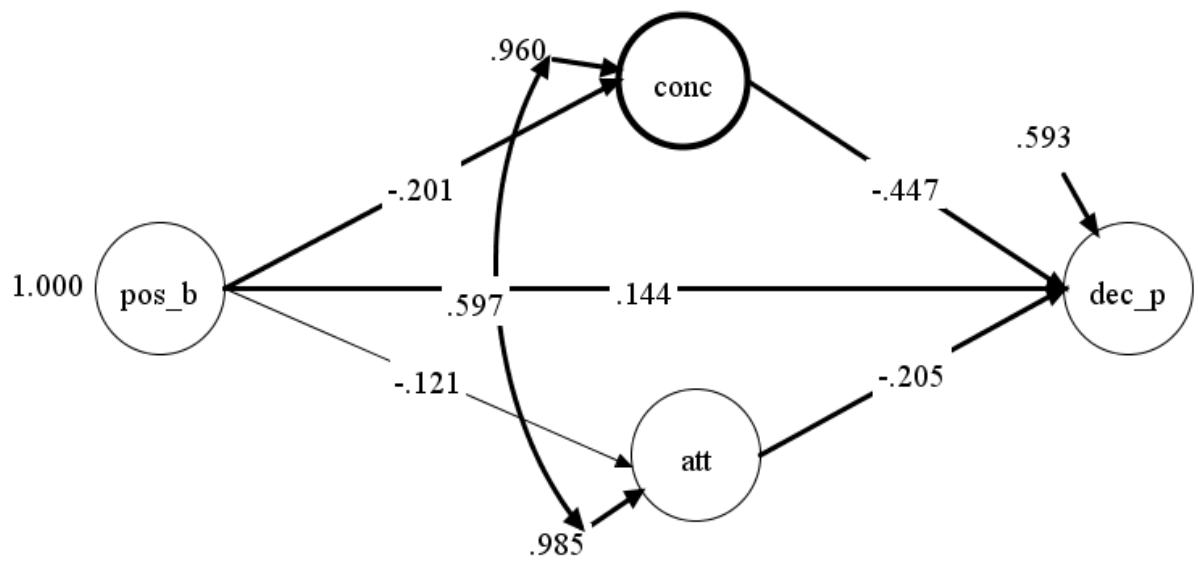

Figure 2. Path diagram of the relationship between positive metacognitive beliefs about procrastination (pos_b), concentration (conc), attitude (att), and decisional procrastination (dec_p). Significant paths $(p<.05)$ are in bold.

\section{Discussion}

The aim of the current study was to test a causal model in which the two self-regulated learning components of attitude and concentration interfered in the relationship between metacognitive beliefs about procrastination and decisional procrastination. In general, the results provided interesting contribution to the research on procrastination from metacognitive and selfregulated learning perspectives.

Findings from structural equation modeling partially confirmed the hypothesized relationships. The alternative model with only positive metacognitive beliefs about procrastination indicated that these beliefs played a more important role in predicting students' self-regulated learning strategies and decisional procrastination than negative metacognitive beliefs. This was not 
surprising given that Spada, Hiou, and Nikcevic (2006) found that negative metacognitive beliefs predicted behavioral procrastination, whereas positive metacognitive beliefs predicted decisional procrastination.

In particular, the estimated model indicated that positive metacognitive beliefs about procrastination had, on the one hand, an adverse impact on concentration and, on the other hand, increase the tendency to postpone decisions. These results can be interpreted in light of Fernie et al.'s (2009) definition of positive metacognitions according to which the belief that procrastination is a useful coping strategy to improve cognitive performance leads students to fix attention on the procrastination itself, thus reducing their levels of concentration and attention on academic tasks. Consequently, they show a limited capacity to process what is happening around them, and a higher tendency to focus on distracting thoughts, emotions, feelings, or situations. Concentration, in turn, was found to negatively predict decisional procrastination: that is, students who did not report good concentration skills were likely to be easily distracted by competing thoughts which determined the tendency to postpone decisions.

The indirect effect of positive metacognitive beliefs on decisional procrastination through concentration was actually demonstrated, suggesting that such beliefs may foster decisional procrastination by predisposing students to intrusive thoughts and feelings which consume the cognitive resources for concentration and attention (Fernie et al., 2009).

As for the positive relationship between positive metacognitions and decisional procrastination, this result supported previous studies (Cao, 2012b; de Palo, Limone, \& Monacis, 2016; de Palo et al., 2017; Fernie et al., 2009; Spada et al., 2006) which demonstrated how these beliefs, when considered a beneficial strategy to improve cognitive performance, lead to the activation of "mental problem-solving" routines, and, consequently, to the postponement of decisions (Fernie et al., 2016). In this sense, the findings obtained in the present study could confirm the observation that positive metacognitive beliefs, similarly to decisional procrastination, could be defined as a form of coping (Fernie \& Spada, 2008; Mann et al., 1997).

Attitude was also negatively related to decisional procrastination, even though this relationships proved to be weaker than the link between concentration and decisional procrastination. This self-regulated learning strategy concerns the will component and it is referred to students' general attitudes toward school: when there is a lack of reasons for succeeding in school, it is difficult to maintain a mind-set that promotes interest in performing successfully academic tasks (Weinstein et al., 2016). Therefore, low levels of attitudes may foster the cognitive process related to the voluntary delay of start or completing tasks, i.e., decisional procrastination, which is a manifestation of students' indecisiveness.

\section{Educational implications}

The present study was carried out using a sample of undergraduate students because procrastination was proved to reach a peak for individuals in their middle-to-late 20s (Cao, 2012b; Ferrari, Johnson, \& McGown, 1995; Ferrari, \& Scher, 2000). Indeed, some suggestions for educational practice could be inferred. Interventions designed to reduce the positive 
metacognitive beliefs about procrastination would help students to set reasonable expectations about the effort needed to complete a task. One possible suggestion could be teaching students to set specific proximal goals to their academic goals (Ganesan, Mamat, Mellor, Rizzuto, \& Kolar, 2014). A second intervention should concern the significance given by students to their academic choice: if their degree course is not seen as relevant to their life goals and attitudes, then it will be a lack of reasons to take responsibility for learning and successfully manage study activities (Grunschel, Patrzek, \& Fries, 2013; Sorić \& Palekčić, 2009). The role of concentration should not be underestimated, as well: learning techniques for focusing attention and maintaining concentration serve to improve learning strategies and help students who are not confident enough about their abilities and tend to postpone their academic work.

\section{Limitations and future directions}

Because the present study was completed using a relatively small sample observed in one subject area, further research was needed to determine the generalizability of the findings to other school or nonacademic contexts. Another limitation of this study concerned the use of self-report measures: despite the reliability and validity of the instruments were warranted, causal conclusions might be affected by systematic response distortions, method variance and/or monomethod bias.

As the cross-sectional design of this study precluded causal inferences, longitudinal and factorial designs should better explain the nature of the relationship between the variables, as well as the efficacy of any intervention. Given that the present research dealt with a form of procrastination, i.e., decisional procrastination, future research should replicate our findings by taking also into account behavioral procrastination, this in light of the debate on the overlapping between the two constructs. Being a multidimensional construct, procrastination should be analyzed by considering other important facets, such as motivational factors, anxiety, etc. With regard to motivation, higher levels of intrinsic motivation, implying the awareness of academic choices, should act as a protective factor against the maladaptive coping strategies of delaying decisional conflicts and the consequent tendency to procrastinate.

To conclude, although the results obtained in this study could only be considered preliminary in nature, they provided a sufficient starting point to examine more in depth the issue of procrastination that is a barrier to academic success.

\section{References}

Anderson, C. J. (2003). The psychology of doing nothing: Forms of decision avoidance result from reason and emotion. Psychological Bulletin, 129, 139-167. doi: 10.1037/00332909.129.1.139

Balkis, M., \& Duru, E. (2015). Procrastination, self-regulation failure, academic life satisfaction, and affective well-being: underregulation or misregulation form. European Journal of Psychology of Education, 31, 439-459. doi: 10.1080/15298868.2013.763404 
Balkis, M., Duru, E., \& Bulus, M. (2013). Analysis of the relation between academic procrastination, academic rational/irrational beliefs, time preferences to study for exams, and academic achievement: a structural model. European Journal of Psychology of Education, 28, 825-839. doi: 10.1007/s10212-012-0142-5

Baumeister, R. F., \& Heatherton, T. F. (1996). Self-regulation failure: An overview. Psychological Inquiry, 7(1), 1-15.

Baumeister, R. F., Heatherton, T. F., \& Tice, D. M. (1994). Losing Control: How and Why People Fail at Self-Regulation. San Diego, CA: Academic Press.

Bentler, P. M., \& Bonett, D. G. (1980). Significance tests and goodness of fit in the analysis of covariance structures. Psychological Bulletin, 88, 588-606. doi:10.1037/00332909.88.3.588

Beswick, G., Rothblum, E. D., \& Mann, L. (1988). Psychological antecedents of student procrastination. Australian Psychologist, 23, 207-217. doi:10.1080/00050068808255605

Cao, L. (2012a). Examining 'active' procrastination from a self-regulated learning perspective. Educational Psychology, 32(4), 515-545. doi: 10.1080/01443410.2012.663722

Cao, L. (2012b). Differences in Procrastination and Motivation between Undergraduate and Graduate Students. Journal of the Scholarship of Teaching and Learning, 12(2), 39-64.

Corkin, D. M., Shirley, L. Y., \& Lindt, S. F. (2011). Comparing active delay and procrastination from a self-regulated learning perspective. Learning and Individual Differences, 21(5), 602-606. doi: 10.1016/j.lindif.2011.07.005

de Palo, V., Limone, P., \& Monacis, L. (2016). Why university students procrastinate their academic tasks. Turkish Online Journal of Educational Technology, Dec. (Special Issue), 1366-1371.

de Palo, V., Limone, P., \& Sinatra, M. (2017). The Cognitive Components of Self-Regulated Learning: Their Effects on Academic Procrastination. Turkish Online Journal of Educational Technology, Dec. (Special Issue), 146-150.

de Palo, V., Monacis, L., Miceli, S., Sinatra, M., \& Di Nuovo, S. (2017). Decisional procrastination in academic settings: The role of metacognitions and learning strategies. Frontiers in Psychology, 8, 973. doi: 10.3389/fpsyg.2017.00973

Deniz, M. E. (2006). The relationships among coping with stress, life satisfaction, decision making styles and decision self-esteem: an investigation with Turkish university students. Social Behavior and Personality: an International Journal, 34, 1161-1170. doi: 10.2224/sbp.2006. 34.9.1161

Di Fabio, A. (2006). Decisional procrastination correlates: personality traits, self-esteem or perception of cognitive failure? International Journal for Educational and Vocational Guidance, 6(2), 109-122. doi: 10.1007/s10775-006-9000-9

Díaz-Morales, J. F., \& Ferrari, J. R. (2015). More time to procrastinators: The role of time perspective. In Time Perspective Theory; Review, Research and Application (pp. 305321). Cham: Springer International Publishing.

Fernie, B. A., McKenzie, A. M., Nikčević, A. V., Caselli, G., \& Spada, M. M. (2016). The contribution of metacognitions and attentional control to decisional procrastination. Journal of Rational-Emotive \& Cognitive-Behavior Therapy, 34, 1-13. doi: 10.1007/s10942-015-0222-y 
Fernie, B. A., \& Spada, M. M. (2008). Metacognitions about procrastination: a preliminary investigation. Behavioural and Cognitive Psychotherapy, 36, 359-364. doi: 10.1017/ s135246580800413x

Fernie, B. A., Spada, M. M., Nikčević, A. V., Georgiou, G. A., \& Moneta, G. B. (2009). Metacognitive beliefs about procrastination: development and concurrent validity of a self-report questionnaire. Journal of Cognitive Psychotherapy, 23, 283-293. doi: 10.1891/0889-8391.23.4.283

Ferrari, J. R. (2001). Procrastination as self-regulation failure of performance: effects of cognitive load, self-awareness, and time limits on 'working best under pressure'. European Journal of Personality, 15(5), 391-406. doi: 10.1002/per.413

Ferrari, J. R. (2010). Still procrastinating? The no regrets guide to getting it done. New York: J. Wiley \& Sons.

Ferrari, J. R., Johnson, J. L., \& McGown, W. G. (1995). Procrastination and task avoidance: Theory, research, and treatment. New York, NY: Plenum Press.

Ferrari, J. R., \& Scher, S. J. (2000). Toward an understanding of academic and nonacademic tasks procrastinated by students: The use of daily logs. Psychology in the Schools, 37(4), 359-366. doi: 10.1002/1520-6807(200007)37:4<367::AID-PITS7>3.0.CO;2-Y

Ganesan, R., Mamat, N. H. B., Mellor, D., Rizzuto, L., \& Kolar, C. (2014). Procrastination and the $2 \times 2$ Achievement Goal Framework in Malaysian Undergraduate Students. Psychology in the Schools, 51(5), 506-516. doi: 10.1002/pits.

Gollwitzer, P. M. (1996). The volitional benefits of planning. In P. M. Gollwitzer \& J. A. Bargh (Eds.), The psychology of action: Linking cognition and motivation to behavior (pp. 287-312). New York, NY: Guilford Press.

Grunschel, C., Patrzek, J., \& Fries, S. (2013). Exploring reasons and consequences of academic procrastination: an interview study. European Journal of Psychology of Education, 28(3), 841-861. doi: 10.1007/s10212-012-0143-4

Howell, A. J., \& Watson, D. C. (2007). Procrastination: associations with achievement goal orientation and learning strategies. Personality and Individual Differences, 43, 167-178. doi: 10.1016/j.paid.2006.11.017

Howell, A. J., Watson, D. C., Powell, R. A., \& Buro, K. (2006). Academic procrastination: The pattern and correlates of behavioural postponement. Personality and Individual Differences, 40(8), 1519-1530.

Hu L., \& Bentler P. M. (1999). Cutoff criteria for fit indexes in covariance structure analysis: Conventional criteria versus new alternatives. Structural Equation Modelling, 6, 1-55. doi:10.1080/10705519909540118

Janis, I. L., \& Mann, L. (1977). Decision Making: A Psychological Analysis of Conflict, Choice and Commitment. New York, NY: Free Press.

Kim, H. Y. (2013). Statistical notes for clinical researchers: Assessing normal distribution using skewness and kurtosis. Restorative Dentistry \& Endodontics, 38(1), 52-54. doi: $10.5395 /$ rde.2013.38.1.52

Klassen, R. M., \& Kuzucu, E. (2009). Academic procrastination and motivation of adolescents in Turkey. Educational Psychology, 29(1), 69-81. doi: 10.1080/01443410802478622

Lay, C. H. (1986). At last, my research article on procrastination. Journal of Research in Personality, 20, 474-495.

(C) Psy, Soc, \& Educ, 2019, Vol. 11(1) 
Little, T. D. (2013). Longitudinal structural equation modeling. New York, NY: Guilford Press.

Little, T. D., Cunningham, W. A., Shahar, G., \& Widaman, K. F. (2002). To parcel or not to parcel: Exploring the question, weighing the merits. Structural Equation Modelling, 9(2), 151-173. doi: 10.1207/S15328007SEM0902_1

Mann, L., Burnett, P., Radford, M., \& Ford, S. (1997). The Melbourne Decision-Making Questionnaire: An instrument for measuring patterns for coping with decisional conflict. Journal of Behavioral Decision Making, 10, 1-19. doi: 10.1002/(SICI)10990771(199703)10:1<1::AID-BDM242>3.0.CO;2-X

Milgram, N. A. (1988). Procrastination in daily living. Psychological Reports, 63, 752-754.

Milgram, N. A., \& Tenne, R. (2000). Personality correlates of decisional and task avoidant procrastination. European Journal of Personality, 14, 141-156. doi: 10.1002/(SICI)1099-0984(200003/04)14:2<141::AID-PER369>3.0.CO;2-V

Milgram, N. A, Srolof, B., \& Rosenbaum, M. (1988). The procrastination of everyday life. Journal of Research in Personality, 22, 197-212.

Monacis, L., de Palo, V., Sinatra, M., Berzonsky, M. D.(2016) The revised identity style inventory: Factor structure and validity in Italian speaking students, Frontiers in Psychology, 7 (JUN), art. no. 883.

Nota, L., \& Soresi, S. (2000). Adattamento italiano del Melbourne Decision Making Questionnaire di Leon Mann (Italian adaptation of Melbourne Decision Making Questionnaire of Leon Mann). Giornale Italiano di Psicologia dell'Orientamento, 1, 38-52.

Orellana-Damacela, L. E., Tindale, R. S., \& Suárez-Balcázar, Y. (2000). Decisional and behavioral procrastination: How they relate to self-discrepancies. Journal of Social Behavior and Personality, 15(5), 225-238.

Rassin, E. (2007). A psychological theory of indecisiveness. Netherlands Journal of Psychology, 63(1), 1-11.

Sorić, I., \& Palekčić, M. (2009). The Role of Students' Interests in Self-Regulated Learning: The Relationship between Students' Interests, Learning Strategies and Causal Attributions. European Journal of Psychology of Education, 24(4), 545-565.

Spada, M. M., Hiou, K., \& Nikčević, A. V. (2006). Metacognitions, emotions, and procrastination. Journal of Cognitive Psychotherapy, 20, 319-326. doi: 10.1891/jcop.20.3.319

Steel, P. (2007). The Nature of Procrastination: A Meta-Analytic and Theoretical Review of Quintessential Self-Regulatory Failure. Psychological Bulletin, 133(1), 65-94. doi: 10.1037/0033-2909.133.1.65

Steel, P. (2010). Arousal, avoidant and decisional procrastinators: Do they exist? Personality and Individual Differences, 48(8), 926-934. doi: 10.1016/j.paid.2010.02.025

Suldo, S. M., Shaunessy, E., Michalowski, J., \& Shaffer, E. J. (2008). Coping strategies of high school students in an International Baccalaureate program. Psychology in the Schools, 45(10), 960-977. doi: 10.1002/pits.20345

Tibbett, T. P., \& Ferrari, J. R. (2015). The portrait of the procrastinator: Risk factors and results of an indecisive personality. Personality and Individual Differences, 82, 175-184. doi: 10.1016/j.paid.2015.03.014 
van Hooft, E. A. J., Born, M. P., Taris, T. W., van der Flier, H., \& Blonk, R. W. B. (2005). Bridging the gap between intentions and behavior: Implementation intentions, action control, and procrastination. Journal of Vocational Behavior, 66(2), 238-256. doi: 10.1016/j.jvb.2004.10.003

Weinstein, C. E., Palmer, D. R., \& Acee, T. W. (2016). Learning and Study Strategies Inventory (LASSI): User's Manual. 3. ed. Clearwater, FL: H \& H Publishing.

Weinstein, C. E., Schulte, A. C., \& Palmer, D. R. (1987). Learning and Study Strategies Inventory. Clearwater, FL: $\mathrm{H} \& \mathrm{H}$ Publishing.

Wells, A. (2000). Emotional Disorders and Metacognition: Innovative Cognitive Therapy. Chichester: Wiley

Wolters, C. A. (2003). Understanding Procrastination From a Self-Regulated Learning Perspective. Journal of Educational Psychology, 95(1), 179-187. doi: 10.1037/00220663.95.1.179

Yilmaz, H., Arslan, C., Sarïcaoğlu, H., \& Yilmaz, S. (2013). An investigation of subjective well-being in terms of coping with stress and decision-making in university students. Middle East Journal of Scientific Research, 14, 1143-1148. doi: 10.5829/idosi.mejsr.2013.14.9.1905

Zhou, M., \& Kam, C. C. S. (2017). Trait procrastination, self-efficacy and achievement goals: the mediation role of boredom coping strategies. Educational Psychology, 37(7), 854872 doi: 10.1080/01443410.2017.1293801.

Zimmerman, B. J., \& Schunk, D. H. (Eds.). (1989). Self-Regulated Learning and Academic Achievement: Theory, Research, and Practice. New York, NY: Springer Verlag. 